\title{
PENGARUH LINGKUNGAN KERJA DAN DISIPLIN KERJA TERHADAP KINERJA KARYAWAN (Study Pada Karyawan Rumah Sakit Islam Banjarmasin)
}

\author{
Winda Andriani ${ }^{1)}$ \\ Rahmi Widyanti2) \\ E-mail: rahmiwidyanti@yahoo.com \\ Husnurropiq ${ }^{3)}$
}

Fakultas ekonomi Universitas islamKalimantan (UNISKA) Banjarmasin

\begin{abstract}
This study aims to determine and analyze Effect of Work Environment and Work Discipline on Employee Performance (Study on Islamic Hospital Banjarmasin), this type of research is quantitative research. Sample taken counted 77 respondents by using Slovin formula. Data collection is taken by usung some technique that is observation, interview, and quetioner by using Likert scale., Statistical analysis using IBM Statistic application version 20.

Based on the result of calculations and testing result obtained work environment variables partially affect the employe performance with tcount3.747>ttable1.667, variable work discipline partially affect the employe performance with tcount4.011>ttable1.667, variable work environment and work discipline partially affect the employe performance with Fcount35.406 > Ftable3.155. The result of subsequent testing based on the coefficient of determination obtained partial work environment effect on employee performance with the regression is 0.378 or $37.8 \%$, the effect of work discipline partially on employee performance with the value of regression is equal to 0.392 or $39.2 \%$, and the last test result effect of work environment and work discipline on employee performance with the regression is 0.489 or $48.9 \%$.

The result of this study can be a reference for various parties to improve employee perpormance. It is necessary to continuously develop employees through work environment. In addition, there should also be attention to work discipline in the organization of the employees.
\end{abstract}

Keywords : Work Environment, Work Discipline, Employe Performance. 


\section{PENDAHULUAN}

Menurut (Logahan, 2009: 3) kinerja merupakan landasan bagi pencapaian tujuan suatu organisasi. Keberhasilan organisasi dalam meningkatkan kinerjanya sangat bergantung pada kualitas sumber daya manusia yang bersangkutan dalam bekerja selama berada pada organisasi tersebut.Lebih lanjut, peranan sumber daya manusia terhadap kinerja organisasi sangatlah penting, keputusan-keputusan sumber daya manusia harus dapat meningkatkan efisiensi bahkan mampu memberikan peningkatan hasil organisasi.Sedangkan (Susilaningsih, 2008: 3) keberhasilan suatu organisasi tidak terlepas dari peningkatan sumber daya manusia. Sumber daya manusia yang unggul dan berkualitas harus selalu dikelola dan ditekankan oleh organisasi untuk dapat mencapai kinerja yang diharapkan.

Disiplin kerja dapat diartikan kesadaran dan kesediaan seseorang mentaati peraturan perusahaan atau organisasi dan norma-norma sosial yang berlaku, dimana karyawan selalu datang dan pulang tepat waku dan mengerjakan semua pekerjaannya dengan baik. (Hasibuan, 2013: 193) Sedangkan (Suprayitno, 2007: 24) penerapan disiplin bagi karyawan diharapkan dapat meningkatkan kinerja karyawan. Disamping itu perlu didukung lingkungan kerja yang baik berupa lingkungan kerja yang dapat menunjang kelancaran, keamanan, keselamatan, kebersihan, serta kenyamanan dalam bekerja dan adanya fasilitas yang memadai sehingga karyawan merasa aman, tenang dan senang dalam menjalankan tugas-tugas yang dibebankan dan menjadi tanggung jawabnya.

Selain disiplin kerja, lingkungan kerja berpengaruh juga terhadap kinerja. Lingkungan kerja adalah lingkungan dimana para karyawan dapat melaksanakan tugasnya sehari-hari dengan keseluruhan sarana dan prasarana kerja yang diperlukan untuk melaksanakan tugas-tugas tersebut. (Sri Widodo, 2015:95)

66 
Tujuan penelitian ini adalah untuk mengkaji pengaruh lingkungan kerja dan disiplin kerja terhadap kinerj karyawan.

\section{TINJAUAN PUSTAKA}

\section{Manajemen sumber daya manusia}

Manajemen sumer daya manusia (MSDM) merupakan bagian dari manajemen keorganisasian yang memusatkan perhatian pada unsur manusia. Unsur manusia (Man) ini berkembng menjadi suatu bidang ilmu khusus untuk mempelajari bagaimana mengatur suatu bidang ilmu khusus untuk mempelajari bagaimana proses pemanfaatan sumber daya manusia secara efektif dan efisien untuk mencapai tujuan tertentu dn dapat memberikan kepuasan bagi semua pihak. MSDM adalah suatu bidang manajemen yag mempelajari hubungan dan peranan manusia dalam organisasi atau perusahaan. Fokus yang dipelajari dalam MSDM adalah masalah yang terkait dengan tenaga kerja manusia. MSDM adalah pendekatan dalam mengelola masalahmasalah manusia.

Mondy (2010:4-5), Manajemen sumber daya manusia adalah utilisasi dari individu-individu untuk mencapai tujuan organisasi. Maka dari itu, manajer-manajer di setiap tingkat harus memperhatikan manajemensumber daya manusia. Pada dasarnya, semua manager menyelesaikan segala sesuatunya dengan mendelegasikan tugas kepada karyawannya, hal ini memerlukan manajemen sumber daya manusia yang efektif.

\section{Lingkungan Kerja}

Sri Widodo (2015:95), lingkungan kerja merupakan lingkungan dimana para karyawan dapat melaksanakan tugasnya sehari-hari dengan keseluruhan sarana dan prasarana kerja yang diperlukan untuk melaksanakan tugas-tugas tersebut. 
Sedarmayanti (2007) dalam Nugroho dan Satrio (2016), menyatakan secara garis besar jenis lingkungan kerja terbagi menjadi dua, yaitu:

(1) Lingkungan kerja fisik

Lingkungan kerja fisik adalah semua keadaan berbentuk fisik yang terdapat disekitar tempat kerja yang dapat mempengaruhi karyawan baik secara langsung maupun tidak langsung. Lingkungan kerja fisik termasuk didalamnya adalah penerangan (cahaya), pewarnaan, kebersihan tempat kerja, sirkulasi udara, tata ruang, peralatan kerja yang tersedia, bau yang tidak sedap dan suara bising`

(2) Lingkungan kerja non fisik

Lingkungan kerja non fisik adalah semua keadaan yang terjadi yang berkaitan dengan hubungan kerja, baik hubungan dengan atasan maupun hubungan sesama rekan kerja, ataupun hubungan dengan bawahan.Lingkungan kerja non fisik termasuk didalamnya adalah suasana kerja, penjelasan tugas dan pengawasan tugas.

\section{Disiplin Kerja}

Hasibuan (2013:193), disiplin kerja dapat diartikan kesadaran dan kesediaan seseorang mentaati peraturan perusahaan atau organisasi dan norma-norma sosial yang berlaku, dimana karyawan selalu datang dan pulang tepat waku dan mengerjakan semua pekerjaannya dengan baik. T. Hani Handoko (2012:208-211) menyatakan ada 2 bentuk disiplin kerja yaitu:

(1) Disiplin Preventif

Disiplin preventif adalah suatu upaya untuk meng ggerakkan pegawai mengikuti dan mematuhi pedoman kerja, aturan-aturan yang digariskan oleh perusahaan.Tujuan dasarnya adalah untuk menggerakkan pegawai berdisiplin diri. Dengan cara preventif, pegawai dapat memelihara dirinya terhadap peraturanperaturan perusahaan atau Institusi.

68 
Pemimpin perusahaan mempunyai tanggungjawab dalam membangun iklim organisasi dengan disiplin preventif.Begitu pula pegawai harus dan wajib mengetahui, memahami semua pedoman kerja serta peraturan-peraturan yang ada dalam organisasi.Disiplin preventif merupakan suatu sistem yang berhubungan dengan kebutuhan kerja untuk semua bagian sistem yang ada dalam organisasi. Jika sistem organisasi baik maka diharapkan akan lebih mudah menggerakkan disiplin kerja.

(2) Disiplin Korektif

Disiplin korektif adalah suatu upaya menggerakkan pegawai dalammenyatukan suatu peraturan dan mengarahkan untuk tetap mematuhi peraturan sesuai dengan pedoman yang berlaku pada perusahaan atau organisasi.Pada disiplin korektif, karyawan yang melanggar displin perlu diberikan sanksi sesuai dengan peraturan yang berlaku.Tujuan pemberian sanksi adalah untuk memperbaiki pegawai pelanggar, memelihara peraturan yang berlaku dan memberikan pelajaran kepada pelanggar.

\section{Kinerja karyawan}

Silalahi (2013:408), kinerja karyawan adalah tingkat pencapaian kerja individu (pegawai) setelah berusaha atau bekerja keras atau hasil akhir dari suatu aktivitas. Dibawah ini merupakan faktor-faktor yang dapat mempengaruhi pencapaian kinerja menurut Kasmir (2016):

(1) Kemampuan dan Keahlian

Merupakan kemampuan atau skill yang dimiliki seseorang dalam melakukan suatu pekerjaan. Semakin memiliki kemampuan dan keahlian maka akan dapat menyelesaikan pekerjaannya secara benar, sesuai dengan yang telah ditetapkan. Artinya karyawan yang memilki kemampuan dan keahlian yang lebih baik, maka 
akan memberikan kinerja yang baik pula demikian sebaliknya. Dengan demikian kemampuan dan keahlian akan mempengaruhi kinerja seseorang.

(2) Pengetahuan

Maksudnya adalah pengetahuan tentang pekerjaan. Seseorang yang memiki pengetahuan tentang pekerjaan secara baik akan memberikan hasil pekerjaan yang baik, demikian sebaliknya. Jadi dapat disimpulkan bahwa pengetahuan tentang pekerjaan akan mempengaruhi kinerja.

(3) Rancangan Kerja

Merupakan rancangan pekerjaan yang akan memudahkan dalam mencapai tujuannya . Artinya jika suatu pekerjaan memiliki rancangan yang baik, maka akan memudahkan untuk menjalankan pekerjaan tersebut secara tepat dan benar. Demikian pula sebaliknya, maka dapat disimplkan bahwa rancangan pekerjaan akan mempengaruhi kinerja seseorang.

(4) Kepribadian

Yaitu kepribadian seseorang atau karakter yang dimiliki seseorang. Setiap orang memiliki kepribadian atau karakter yang baik akan dapat melakukan pekerjaan secara sungguh-sungguh penuh tanggung jawab sehingga hasil pekerjaan juga baik.

(5) Motivasi kerja

Motivasi kerja merupaka dorongan bagi seseorang untuk melakukan pekerjaan. Jika karywan memilki dorongan yang kuat dari dalm dirinya atau dorongan dari luar dirinya(misalnya dari pihak perusahaan), maka karyawan akan terangsang atau terdorong untuk melakukan pekerjaan dengan baik. Pada akhirnya dorongan atau rangsangan baik dari dalam maupun dari luar diri seseorang akan menghasilkan kinerja yang baik. 
(6) Kepemimpinan

Kepemimpinan merupakan perilaku seorang pemimpin dalam mengatur, mengelola dan memerintah bawahannya untuk mengerjakan suatu tugas dan tanggung jawab yang diberikannya.

(7) Gaya kepemimpinan

Merupakan gaya atau sikap seorang pemimpin dalam menghadapi atau memerintah bawahannya.

(8) Budaya organisasi

Merupakan kebiasaan-kebiasaan atau norrma-norma yang berlaku dan dimiliki oleh suatu organisasi atau perusahaan.Kebiasaan-kebiasaan atau norma-norma ini mengatur hal-hal yang berlaku dan diterima secara umum serta harus dipatuhi oleh segenap anggota suatu perusahaan atau organisasi.

(9) Kepuasan kerja

Merupakan perasaan senang atau gembira, atau perasaan suka seseorang sebelum dan setelah melakukan suatu pekerjaan. Jika karyawan merasa senang atau gembira atau suka untuk bekerja, maka hasil pekerjaan akan baik pula.

(10) Lingkungan kerja

Merupakan suasana atau kondisi disekitar lokasi tempat bekerja.Lingkungan kerja dapat berupa ruangan, layout, sarana dan prasarana serta hubungan kerja dengan sesama rekan kerja

(11) Loyalitas

Merupakan kesetiaan karyawan untuk tetap bekerja dan membela perusahaan di mana tempatnya bekerja. Kesetiaan ini ditunjukan dengan terus bekerja sungguhsungguh sekalipun suatu perusahaan dalam kondisi kurang baik.

(12) Komitmen

71

Jurnal Komunikasi Bisnis dan Manajemen

Vol.7 No.2 Juli 2020 
Merupakan kepatuhan karyawan untuk menjalankan kebijakan atau peraturan perusahaan dalam bekerja.Komitmen juga dapat diartikan kepatuhan karyawan kepada janji-janji yang telah dibuatnya. Atau dengan kata lain komitmen merupakan kepatuhan untuk menjalankan keputusan yang telah dibuat

(13) Disiplin kerja

Merupakan usaha karyawan untuk menjalankan aktivitas kerjanya secara sungguhsungguh.Disiplin kerja dalam hal ini dapat berupa waktu, misalkan waktu kerja selalu tepat waktu. Kemudian disiplin dalam mengerjakan apa yang diperintahkan kepadanya sesuai dengan perintah yang harus dikerjakan. Karyawan yang disiplin akan mempengaruhi kinerja.

\section{Hipotesis}

$\mathrm{H}_{1}$ : Terdapat pengaruh lingkungan kerja secara parsial terhadap kinerja karyawan pada Rumah Sakit Islam Banjarmasin.

$\mathrm{H}_{2}$ : Terdapat pengaruh disiplin kerja secara parsial terhadap kinerja karyawan pada Rumah Sakit Islam Banjarmasin.

$\mathrm{H}_{3}$ : Terdapat pengaruh lingkungan kerja dan disiplin kerja secara simultan terhadap kinerja karyawan pada Rumah Sakit Islam Banjarmasin.

\section{METODE PENELITIAN}

Penelitian ini menggunakan kombinasi pendekatan kuantitatif (metode survei) dan pendekatan kualitatif.Metode survei adalah metode yang mengambil contoh data dari satu populasi dan menggunakan kuesioner sebagai alat pengumpulan data yang pokok (Singarimbun dan Effendi, 2008). Dengan memadukan kedua pendekatan tersebut diharapkan upaya pemahaman terhadap kesejahteraan karyawan sayang berpengaruh terhadap produktivitas kerja, faktor-faktor yang mempengaruhi produktivitas kerja dapat dilakukan secara lebih komprehensif. 
Populasi adalah wilayah generalisasi yang terdiri atas: obyek/subjek yang mempunyai kualitas dan karakteristik tertentu yang diterapkan oleh peneliti untuk dipelajari dan kemudian ditarik kesimpulannya, (Sugiyono, 2007:115), sedangkan populasi yang di gunakan dalam penelitian adalah karyawan Rumah Sakit Islam Banjarmasin.Sedangkan sampel di ambil 77 dari total populasi 330 orang menggunakan rumus slovin pengumpulan data di ambil dengan menggunakan teknik observasi, wawancara dan kuesioner.

\section{Definisi operasional}

Definisi operasional merupakan bagian dari penelitian yang memberikan penjelasan variabel-variabel operasional agar dapat diukur. Adapun definisi operasional penelitian ini adalah sebagai berikut:

1. Lingkungan Kerja $\left(X_{1}\right)$, indikatornya Lingkungan bersih, Ruang kerja teratur, Hubungan karyawan dengan atasan, Hubungan sesama rekan kerja.

2. Disiplin Kerja $\left(\mathrm{X}_{2}\right)$, indikatornya adalah Mematuhi semua peraturan perusahaan, Penggunaan waktu secara efektif, Tanggung jawab dalam pekerjaan dan tugas, danTingkat absensi.

3. Kinerja Karyawan (Y) indikatornya adalah Kualitas, Ketepatan Waktu, Efektivitas, Kemandirian, dan Komitmen Kerja.

Metode analisis data berguna untuk mengetahui seberapa besar pengaruh program kesejahteraan karyawan,yaitu dalam bentuk langsung dan tidak langsung terhadap semangat kerja karyawan. Dengan menggunakan metode ini diharapkan hasil yang diperoleh lebih terarah, dan menulis menggunakan program SPSS versi 20. 


\section{HASIL PENELITIAN}

\section{Hasil Uji validitas dan reabilitas}

Berdasarkan hasil uji validitas dapat diketahui semua item dalam penelitian dapat dikatakan valid, karena rhitung> rtabel. Sedangkan hasil uji reliabilitas dapat dilihat bahwa nilai cronbach's alpha semua variabel dalam penelitian ini lebih besar dari 0,60 hal itu menandakan bahwa semua pernyataan yang digunakan pada penelitian ini bersifat reliabel.

\section{Analisis regresi linier berganda}

Penelitian ini bertuan untuk mengethui pengaruh program kesejahteraan karyawan terhadap produktivitas kerja karyawan. Sebelum menguji moderasi terlebih dahulu peneliti sampaikan hasil pengujian pengaruh kesejahteraan karyawan terhadap produktivitas kerja karyawan sebagai berikut.

\section{Coefficients $^{a}$}

\begin{tabular}{|c|c|c|c|c|}
\hline \multicolumn{2}{|c|}{ Model } & \multicolumn{2}{|c|}{ Unstandardized Coefficients } & \multirow{2}{*}{$\begin{array}{c}\begin{array}{c}\text { Standardized } \\
\text { Coefficients }\end{array} \\
\text { Beta }\end{array}$} \\
\hline & & B & Std. Error & \\
\hline \multirow{3}{*}{1} & (Constant) & 4.628 & 1.790 & \\
\hline & Lingkungan kerja & .274 & .073 & .381 \\
\hline & Disiplin kerja & .465 & .116 & .407 \\
\hline
\end{tabular}

a. Dependent Variabel: kinerja karyawan

Sumber: data diolah, 2017

Berdasarkan tabel diatas dapat diketahui hasil uji regresi linear berganda sebagai berikut:

$$
\mathrm{Y}=4.628+0.274 \mathrm{X} 1+0.465 \mathrm{X} 2+\mathrm{e}
$$

1. Konstanta $(\mathrm{a})=4.628$ menunjukkan nilai konstanta, dimana jika variabel $\mathrm{X} 1, \mathrm{X} 2=0$ maka kinerja karyawan pada Rumah Sakit Islam Banjarmasin tidak meningkatkan lingkungan kerja dan disiplin kerja sehingga lingkungan kerja dan disiplin kerja bernilai tetap. 
2. Koefisien $(X 1)=0.274$ hasil tersebut menunjukkan bahwa lingkungan kerja berpengaruh positif terhadap kinerja karyawan, sehingga apabila lingkungan kerja pada Rumah Sakit Islam Banjarmasin dinaikkan sebesar satu satuan maka kinerja karyawan akan naik sebesar 0.274 satuan.

3. Koefisien $(X 2)=0.465$ hasil tersebut menunjukkan bahwa disiplin kerja berpengaruh positif terhadap kinerja karyawan, sehingga apabila disiplin kerja dinaikkan sebesar satu satuan maka kinerja karyawan akan naik sebesar 0.465 satuan.

\section{Uji Simultan (F)}

Berikut uji pengaruh secara simultan variabel lingkungan kerjadan disiplin kerja di bawah ini:

ANOVA $^{a}$

\begin{tabular}{|rl|r|r|r|r|r|r|}
\hline \multicolumn{2}{|r|}{ Model } & $\begin{array}{r}\text { Sum of } \\
\text { Squares }\end{array}$ & Df & $\begin{array}{r}\text { Mean } \\
\text { Square }\end{array}$ & Fhitung & Ftabel & Sig. \\
\hline \multirow{2}{*}{1} & Regression & 283.767 & 2 & 141.884 & 35.406 & 3.155 & $.000^{\mathrm{b}}$ \\
& Residual & 296.544 & 74 & 4.007 & & \\
& Total & 580.312 & 76 & & & \\
\hline
\end{tabular}

a. Dependent Variable: Kinerja Karyawan

b. Predictors: (Constant), Disiplin kerja, Lingkungan Kerja

Pada tabel diatas diperoleh nilai Fhitung $=35.406$ dengan menggunakan Confidence Interval 95\% ( $\alpha=0.05)$ maka dari tabel distribusi $\mathrm{F}$ diperoleh nilai 3.155 dengan

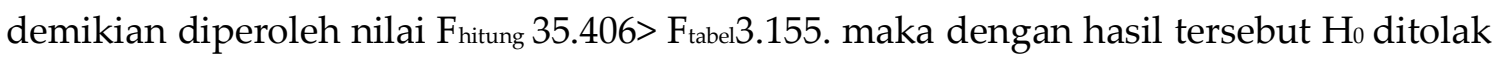
dan $\mathrm{H}_{1}$ diterima. Dengan hasil tersebut dapat diketahui bahwa lingkungan kerja dan disiplin kerja berpengaruh terhadap kinerja karyawan Rumah sakit Islam Banjarmasin

Berdasarkan hasil uji simultan diatas, dapat disimpulkan bahwa semakin bagus lingkungan kerja dan disiplin kerja karyawan maka akan semakin baik pula kinerja karyawan di Rumah Sakit Islam Banjarmasin. 


\section{Uji Parsial}

Uji pengaruh secara parsial lingkungan kerja dan disiplin kerja dapat dilihat pada tabel berikut:

\begin{tabular}{|c|c|c|c|c|c|c|}
\hline \multirow[t]{2}{*}{ Model } & \multicolumn{2}{|c|}{$\begin{array}{c}\text { Unstandardized } \\
\text { Coefficients }\end{array}$} & \multirow{2}{*}{$\begin{array}{c}\begin{array}{c}\text { Standardize } \\
\mathrm{d} \\
\text { Coefficients }\end{array} \\
\text { Beta }\end{array}$} & \multirow[t]{2}{*}{ thitung } & \multirow[t]{2}{*}{ tabel } & \multirow[t]{2}{*}{ Sig. } \\
\hline & B & $\begin{array}{l}\text { Std. } \\
\text { Error }\end{array}$ & & & & \\
\hline (Constant) & 4.628 & 1.790 & & 2.586 & 1.667 & .012 \\
\hline Lingkungan Kerja & .274 & .073 & .381 & 3.747 & 1.667 & .000 \\
\hline Disiplin kerja & .465 & 116 & 407 & 4.011 & 1.667 & .000 \\
\hline
\end{tabular}

Dependent Variabel: kinerja karyawan

Sumber: data diolah, 2017

Pada tabel di atas telah diperoleh masing-masing thitung dari variabel. Selanjutnya nilai thitungakan dibandingkan dengan nilai tabel. Dengan menggunakan $\alpha=$ 0.05 atau 5\% dan dengan menggunakan rumus $\mathrm{df}=\mathrm{n}-2$ maka maka nilai tabel nya adalah1.667.Pengaruh parsial dari variabel lingkungan kerja $\left(X_{1}\right)$ diperoleh dengan nilai thitung sebesar 3.747, dengan demikian maka thitung $>$ tabelsebesar 1.667, dengan hasil tersebut maka $\mathrm{H}_{0}$ ditolak dan $\mathrm{H}_{1}$ diterima, hal ini berarti variabel lingkungan kerja berpengaruh terhadap kinerja karyawan di Rumah Sakit Islam Banjarmasin.

Pengaruh parsial dari variabel disiplin kerja $\left(\mathrm{X}_{2}\right)$ diperoleh nilai thitung sebesar 4.011, dengan demikian maka thitung 4.011> tabel1.667dengan hasil tersebut maka $\mathrm{H}_{0}$ ditolak dan $\mathrm{H}_{1}$ diterima. Hal ini berarti variabel disiplin kerja berpengaruh terhadap kinerja karyawan di Rumah Sakit Islam Banjarmasin. 


\section{Koefisien determinasi}

Koefisien Determinasi $\left(\mathrm{R}^{2}\right)$ hasil regresi dapat dilihat pada tabel berikut:

\begin{tabular}{|c|c|c|c|c|}
\hline \multicolumn{5}{|c|}{ Model Summary ${ }^{b}$} \\
\hline Model & $\mathrm{R}$ & R Square & Adjusted R Square & Std. Error of the Estimate \\
\hline 1 & $.699^{a}$ & .489 & 475 & 2.00184 \\
\hline
\end{tabular}

a. Predictors: (Constant), Disiplin kerja, Lingkungan Kerja

b. Dependent Variable: Kinerja Karyawan

Sumber: data diolah, 2017

Berdasarkan tabel diatas nilai $\mathrm{R}$ sebesar 0.699, hal ini menunjukkan bahwa hubungan antara variabel lingkungan kerja dan disiplin kerja terhadap kinerja karyawan cukup baik. Untuk nilai koefisien Determinasi $\mathrm{R}^{2}$ dari hasil regresi adalah sebesar 0.489 atau 48.9\%, hal ini berarti kinerja pada Rumah Sakit Islam Banjarmasin dipengaruhi 48.9\%oleh lingkungan kerja dan disiplin kerja, sedangkan 51.1\% dipengaruhi oleh faktor lain yang tidak ada di dalam penelitian.

\section{Pembahasan}

Berdasarkan hasil pengujian hipotesis pertama yang berbunyi, ada pengaruh lingkungan kerja secara parsial terhadap kinerja karyawan pada Rumah Sakit Islam Banjarmasin yang telah dilakukan sebelumnya, didapatkan variabel lingkungan kerja berpengaruh secara parsial terhadap kinerja karyawan Rumah Sakit Islam Banjarmasin dibuktikan dengan thitung $3.747>t_{\text {tabel}} 1.667$ berarti hipotesis pertama diterima. Hasil penelitian ini mendukung penelitian terdahulu yang dilakukan oleh Sutono dan Suroso (2009), Suddin dan Sudarman (2010), Widodo (2010), Ghoniyah dan Masurip (2011) yang membuktikan bahwa lingkungan kerja berpengaruh positif dan signifikan terhadap kinerja karyawan.

Hasil pengujian hipotesis kedua yang berbunyi, ada pengaruh disiplin kerja secara parsial terhadap kinerja karyawan pada Rumah Sakit Islam Banjarmasin yang 77 
telah dilakukan sebelumnya, didapatkan variabel disiplin kerja berpengaruh secara parsial terhadap kinerja karyawan Rumah Sakit Islam Banjarmasin dibuktikan dengan thitung4.011>ttabel1.667 berarti hipotesis kedua diterima. Hasil penelitian ini mendukung penelitian terdahulu yang dilakukan oleh Yoga Arsyenda (2013),menyatakan bahwa disiplin kerja berpengaruh positif dan signifikan terhadap kinerja karyawan.

Hasil pengujian hipotesis ketiga yang berbunyi, ada pengaruh lingkungan kerja dan disiplin kerja secara simultan terhadap kinerja karyawan pada Rumah Sakit Islam Banjarmasin yang telah dilakukan sebelumnya, didapatkan variabel lingkungan kerja dan disiplin kerja berpengaruh secara simultan terhadap kinerja karyawan Rumah Sakit Islam Banjarmasin dibuktikan denganFhitung 35.406> Ftabel3.155berarti hipotesis ketiga diterima. Hasil penelitian ini mendukung penelitian terdahulu yang dilakukan oleh Diah dan Eddy (2015) dan Ambarwati (2015) secara simultan dapat disimpulkan bahwa lingkungan kerja dan disiplin kerja berpengaruh signifikan terhadap kinerja karyawan Rumah Sakit Islam Banjarmasin.

Hasil pengujian hipotesis selanjutnya berdasarkan nilai regresi ada pengaruh lingkungan kerja secara parsial terhadap kinerja karyawan pada Rumah Sakit Islam Banjarmasin sebesar 0.378 atau $37.8 \%$, ada pengaruh disiplin kerja secara parsial terhadap kinerja karyawan pada Rumah Sakit Islam Banjarmasin sebesar 0.392 atau $39.2 \%$, dan ada pengaruh lingkungan kerja dan disiplin kerja secara simultan terhadap kinerja karyawan pada Rumah Sakit Islam Banjarmasin sebesar 0.489 atau 48.9\%.

\section{KESIMPULAN}

Berdasarkan hasil analisis data dan pembahasan pada bab sebelumnya, hasil penelitian ini dapat disimpulkan sebagai berikut:

1) Terdapat pengaruh lingkungan kerja secara parsial terhadap kinerja karyawan pada Rumah Sakit Islam Banjarmasin. Dibuktikan dengan athitung3.747 >ttabelsebesar1.667 , dengan hasil tersebut maka $\mathrm{H}_{0}$ ditolak dan $\mathrm{H}_{1}$ diterima, hal ini berarti variabel 
lingkungan kerja berpengaruh terhadap kinerja karyawan di Rumah Sakit Islam Banjarmasin. Dan terdapat pengaruh lingkungan kerja secara parsial terhadap kinerja karyawan pada Rumah Sakit Islam Banjarmasin dengan nilai koefisien Determinasi $\mathrm{R}^{2}$ dari hasil regresi adalah sebesar 0.378 atau $37.8 \%$.

2) Terdapat pengaruh disiplin kerja secara parsial terhadap kinerja karyawan pada Rumah Sakit Islam Banjarmasin. Dibuktikan dengan thitung $4.011>$ ttabel 1.667 dengan hasil tersebut maka $\mathrm{H}_{0}$ ditolak dan $\mathrm{H}_{1}$ diterima. Hal ini berarti variabel disiplin kerja berpengaruh terhadap kinerja karyawan di Rumah Sakit Islam Banjarmasin. Dan terdapat pengaruh disiplin kerja secara parsial terhadap kinerja karyawan pada Rumah Sakit Islam Banjarmasin dengan nilai koefisien Determinasi $\mathrm{R}^{2}$ dari hasil regresi adalah sebesar 0.392 atau $39.2 \%$.

3) Terdapat pengaruh lingkungan kerja dandisiplin kerja secara simultan terhadap kinerja karyawan pada Rumah Sakit Islam Banjarmasin.Dibuktikan dengan Pada tabel diatas diperoleh nilai $F_{\text {hitung }}=35.406$ dengan menggunakan Confidence Interval 95\% $(\alpha=0.05)$ maka dari tabel distribusi $\mathrm{F}$ diperoleh nilai 3.155dengan demikian diperoleh nilai Fhitung 35.406> Ftabel 3.155. maka dengan hasil tersebut $\mathrm{H}_{0}$ ditolak dan $\mathrm{H}_{1}$ diterima. Dengan hasil tersebut dapat diketahui bahwa lingkungan kerja dan disiplin kerja berpengaruh terhadap kinerja karyawan di Rumah Sakit Islam Banjarmasin. Dan terdapat pengaruh lingkungan kerja dan disiplin kerja secara simultan terhadap kinerja karyawan pada Rumah Sakit Islam Banjarmasin dengan nilai koefisien Determinasi $\mathrm{R}^{2}$ dari hasil regresi adalah sebesar 0.489 atau $48.9 \%$.

\section{DAFTAR PUSTAKA}

A.A. Anwar Prabu Mangkunegara. (2009). Manajemen Sumber Daya Manusia. Bandung: PT. Remaja Rosdakarya.

Ambarwati Gustiatun (2015). Pengaruh Kompensasi, Disiplin Kerja Dan Lingkungan Kerja terhadap Kinerja dengan Komitmen Organisasi Sebagai Variabel Intervening Pada PT 
Cartenz Adventure Karanganyar. Tesis dipublikasi, Program Magister Manajemen STIE-AUB Surakarta.

Arsyenda, Yoga. 2013. "Pengaruh Motivasi Kerja dan Disiplin Kerja Terhadap Kinerja PNS (Studi Kasus: BAPPEDA Kota Malang)".Jurnal Ilmiah. Malang: Fakultas Ekonomi dan Bisnis, Universitas Brawijaya.

Badudu, J.S, Sultan Mohammad Zain, 2001. Kamus Umum Bahasa Indonesia, Jakarta: Pustaka Sinar Harapan.

Dessler, Gary, 2011. Manajemen Sumber Daya Manusia. Penerbit Indeks, Jakarta.

Diah Indriani Suwondo dan Eddy Madiono Sutanto (2015), "Pengaruh Lingkungan Kerja dan Disiplin Kerja Terhadap Kinerja Karyawan,"Jurnal Manajemen dan Kewirausahaan, Vol.17, No.2, hal. 142.

Galih Rakasiwi. 2015. "Pengaruh Motivasi, Kepuasan Kerja, dan Disiplin Kerja Terhadap Kinerja Pegawai (Studi Empiris pada Satuan Polisi Pamong Praja Kabupaten Karanganyar)". Jurnal Ekonomi dan Bisnis. Surakarta: Universitas Muhammadiyah Surakarta, Vol1, No.2.

Ghoniyah, Nunung dan Masurip. 2011. "Peningkatan Kinerja Karyawan Melalui Kepemimpinan, Lingkungan Kerja dan Komitmen".Jurnal Dinamika Manajemen (JDM). Vol. 2.No. 2.Hal. 118 - 129. Semarang: Universitas Islam Sultan Agung (UNISSULA).

Ghozali, Imam. 2009. Ekonometrika Teori, Konsep dan Aplikasi dengan SPSS17. Semarang: Badan Penerbit Universitas Diponegoro.

Handoko, T. Hani. 2012. Manajemen Personalia dan Sumber Daya Manusia. Yogyakarta: BPFE.

Hasibuan. (2010). Manajemen SumberDaya Manusia. Jakarta: Bumi Aksara.

Hasibuan, Malayu. 2012. "Manajemen Sumber Daya Manusia".Jakarta: PT Bumi Aksara.

Hasibuan, Malayu. 2013. Manajemen SumberDaya Manusia. Jakarta: Bumi Aksara.

Kasmir. 2016. Analisis Laporan Keuangan. Jakarta: Raja Grafindo Persada.

Logahan, Jerry Marcellinus. 2009. "Pengaruh Lingkungan Kerja dan Stres Pekerjaan Terhadap Kinerja Pekerjadi PT Nemanac Rendem".Tarakanita.

80

Jurnal Komunikasi Bisnis dan Manajemen

Vol.7 No.2 Juli 2020 
Mondy, R. Wayne, 2010. Human Resource Management Eleventh Edition. New Jersey: Prentice Hall.

Noor, Juliansyah. 2011. Metodologi Penelitian: Skripsi, Tesis, Disertasi, Dan Karya Ilmiah. Jakarta: kencana Prenadamedia Group.

Nugroho, B.,dan Satrio, B. (2016). Pengaruh Motivasi dan Lingkungan Kerja Terhadap Kinerja Karyawan Auto 2000 Sungkono Surabaya.Jurnal Ilmu dan Riset Manajemen Vol 5 No 4.

Nur, Hiksan. 2012. Implementasi Program Keselamatan dan Kesehatan Kerja Terhadap Produktivitas Karyawan pada PT Pertamina (Persero) Terminal BBM Makassar. Skripsi. Makassar: Jurusan Manajemen Fakultas Ekonomi dan Bisnis Universitas Hasanuddin.

Rivai, Veithzal. 2011. Manajemen Sumber Daya Manusia untuk Perusahaan: dari Teori ke Praktik, Jakarta: Raja Grafindo Persada.

Robbins, Stephen, 2006. "Perilaku Organisasi". Prentice Hall, edisi kesepuluh Sabardini, 2006, "Peningkatan Kinerja Melalui Perilaku Kerja Berdasarkan Kecerdasan Emosional". Telaah Bisnis, Vol.7,No.1.

Sedarmayanti. (2011). Manajemen Sumber Daya Manusia, Reformasi Birokrasi dan Manajemen Pegawai Negeri Sipil (cetakan kelima). Bandung: PT Refika Aditama.

Silalahi, Ulber. 2013. Asas-Asas Manajemen. Cetakan Kedua, Bandung: PT. Refika Aditama.

Soedarso, Sri Widodo. 2015. Sistem Informasi Manajemen, Bandung: Manggu Media.

Suddin, Alwi dan Sudarman. 2010. “Pengaruh Kepemimpinan, Motivasi, dan Lingkungan Kerja terhadap Kinerja Pegawai Kecamatan Laweyan Kota Surakarta". Jurnal Manajemen Sumberdaya Manusia.Vol. 4.No. 1.Juni 2010.Hal.1 8. Surakarta: Universitas Slamet Riyadi Surakarta.

Sugiyono. 2014. Metode Penilitian Kuantitatif, Kualitatif, dan RED,Bandung: Alfabeta.

Sukmawati, Ferina. 2008. “Pengaruh Kepemimpinan, Lingkungan Kerja Fisik, Dan Kompensasi Terhadap Kinerja Karyawan Di. PT. Pertamina (Persero) UPMS III Terminal Transit Utama Pekalongan, Indramayu".Jurnal Ekonomi dan Bisnis. Vol. 2.No. 2.November.Hal.175 -191.Indramayu.

81

Jurnal Komunikasi Bisnis dan Manajemen

Vol.7 No.2 Juli 2020 
Suprayitno, dan Sukir. 2007. "Pengaruh Disiplin Kerja, Lingkungan Kerja, dan Motivasi Kerja Terhadap Kinerja Karyawan".Dalam Jurnal Manajemen Sumber Daya Manusia, Volume 2 No. 1. Hal 23-34. Karanganyar: Universitas Slamet Riyadi Surakarta.

Susilaningsih, Nur. 2008. "Pengaruh Kepemimpinan, Motivasi, Pengawasan, dan Lingkungan Kerja Terhadap Kinerja Pegawai (Studi Pada Badan Perencanaan Pembangunan Daerah Kabupaten Wonogiri)". Dalam Jurnal Excellent, Volume 1 No. 2. Surakarta: STIE AUB Surakarta.

Sutono dan Iwan Suroso. 2009. "Pengaruh Reward Pelatihan Dan Lingkungan Kerja Yang Berdampak Pada Peningkatan Kinerja Pengelola BMT Bus Lasem". Analisis Manajemen. Vol. 4.No. 1.Desember 2009.Hal.40 -56. Universitas Muria. Kudus.

Sutrisno, Edy. 2011. Manajemen Sumber Daya Manusia. Jakarta: Kencana.

Widodo, Tri. 2010. "Pengaruh Lingkungan Kerja, Budaya Organisasi, Kepemimpinan terhadap Kinerja (Studi Pada Pegawai Kecamatan Sidorejo Kota Salatiga)".Among Makarti.Vol. 3.No. 5.Juli 2010.Hal.14 -35.STIE AMA.Salatiga. 
